Navigation Physics 1(1)(2019)
Navigation Physics
Journal of Physics Education

\title{
Pengembangan Multimedia Interaktif Terintegrasi dengan LKS Pada Pokok Bahasan Pesawat Sederhana
}

\author{
Ade Suseno $^{1}$, Riswanto ${ }^{2 *}$, dan Partono ${ }^{3}$ \\ 1,2,3 Universitas Muhammadiyah Metro, Lampung \\ * E-mail: rumbiariswan@gmail.com
}

\begin{tabular}{|c|c|}
\hline Info Artikel & Abstract \\
\hline $\begin{array}{l}\text { Sejarah Artikel: } \\
\text { Diterima Januari } 2019 \\
\text { Disetujui Mei } 2019 \\
\text { Dipublikasikan Juni } 2019\end{array}$ & $\begin{array}{l}\text { The pre-survey result of the problem school that media that used in school } \\
\text { have not assisted student learning, and some teachers use an interactive } \\
\text { multimedia..The purpose of this research is to produce an integrated } \\
\text { interactive multimedia development with student worksheet on simple } \\
\text { machine subject by using powerpoint. The type of this research is Reseach } \\
\text { and Development. The model development that used is the ADDIE } \\
\text { development model includes } 5 \text { step: Analysis, Design, Development, } \\
\text { Implementation, and Evaluation. The feasibility of the result product could } \\
\text { be reviewed in } 3 \text { aspects: software engineering aspects, visual } \\
\text { communication aspect and learning design aspects. The results that the } \\
\text { powerpoint have fulfill the criteria that showed by validation with a very } \\
\text { feasible and good criteria. The product assessment by media expert reached } \\
89.1 \% \text { and material experts reached } 89.0 \% \text {. Furthermore, the product } \\
\text { assessment by teacher response reaches } 90.5 \% \text { and product assessment by } \\
\text { Student response reaches } 87.1 \% \text {. }\end{array}$ \\
\hline
\end{tabular}

How to Cite: Suseno, A., Riswanto, Partono. (2019). Pengembangan Multimedia Interaktif Terintegrasi dengan LKS Pada Pokok Bahasan Pesawat Sederhana, Navigation Physics, 1 (1), 22-26.

\section{PENDAHULUAN}

Ariani dan Haryanto (2010:25) menyatakan multimedia interaktif adalah suatu multimedia yang dilengkapi dengan alat pengontrol yang dapat dioprasikan oleh pengguna sehingga pengguna dapat memilih apa yang dihendaki untuk proses selanjutnya. Multimedia ini juga terdiri dari teks, grafis, gambar, poto, audio dan animasi secara terintegrasi. Contoh multimedia interaktif adalah: multimedia pembelajaran interaktif, dan apilikasi game. Arsyad (2013:162) Multimedia masih belum jelas, secara sederhana ia diartikan sebagai lebih dari satu media. Ia bisa berupa kombinasi antara teks, grafik, animasi, suara dan video. Definisi sederhana ini telah pula mencakup salah satu jenis kombinasi yang diuraikan pada bagian terdahulu, misalnya kombinasi slide dan tape audio. Selain itu hasil penelitian Wulan, dkk (2019) mengungkapkan bahwa penggunaan mobile pocket book berbasis android yang dipasang pada alat komuniksai handphone menggunakan adobe flash yang dikembangkan dapat menunjang proses pembelajaran dan memberikan kemudahan bagi siswa untuk belajara secara mandiri.

Arsyad (2013:164) menyatakan Microsoft powerpoint adalah salah satu program presentasi yang banyak digunakan orang untuk mempresentasikan slidenya. Dalam dokumen ini sudah disertakan langkah-langkah yang akan ditempuh untuk menggunakannya beberapa fitur dari Ms.PowerPoint. Membuka Ms. PowerPoint langkah pertama yang harus dilakukan adalah membuka Ms. PowerPoint yang ada di computer anda. Klik start, pilih All Program, pilih Microsoft Office, dan klik Microsoft Office PowerPoint. Anggraini (2012:212) Media powerpoint merupakan media yang menggunakan teknologi canggih yaitu komputer. Dalam pembelajaran, media berfungsi untuk menyampaikan pesan pembelajaran. Sedangkan powerpoint adalah salah satu softwer yang ada dalam komputer, yang bisa tampil dengan slide show dan menggunakan animasi yang bisa bergerak-gerak.

Trianto (2009:222) menyatakan Lembar kegiatan siswa adalah panduan siswa yang digunakan untuk melakukan kegiatan penyelidikan atau pemecahan masalah. Lembar kegiatan siswa (LKS) memuat 
sekumpulan kegiatan mendasar yang harus dilakukan oleh siswa untuk memaksimalkan pemahaman dalam upaya pembentukan kemampuan dasar sesuai indikator pencapaian hasil belajar yang harus ditempuh. Melalui penyediaan media belajar pada kegiatan eksperimen sehingga situasi belajar menjadi lebih bermakna, dan dapat terkesan dengan baik pada pemahaman siswa. Trianto (2011:111) menyatakan lembar kerja siswa adalah panduan siswa yang digunakan untuk melakukan kegiatan penyelidikan atau pemecahan masalah. Lembar kegiatan siswa dapat berupa panduan untuk latihan pengembangan aspek kognitif maupun panduan untuk pengembangan semua aspek pembelajaran dalam bentuk panduan eksperimen atau demonstrasi. Lembar kerja siswa (LKS) memuat sekumpulan kegiatan mendasar yang harus dilakukan oleh siswa untuk memaksimalkan pemahaman dalam upaya pembentukan kemampuan dasar sesuai indikator pencapaian hasil belajar yang harus ditempuh.

Harjono (2007:36) pesawat sederhana adalah semua peralatan yang memudahkan manusia dalam melakukan kerja dan usaha. Pesawat tidak selalu berupa peralatan yang cangih. Peralatan yang sangat sederhana pun dapat disebut pesawat misalnya sendok, obeng, sekrup, dan sapu. Sementara itu Triatmanto (2007:142) menjelaskan bahwa pesawat sederhana adalah peralatan yang membantu mempermudah kita dalam Melakukan suatu pekerjaan. Peralatan yang sangat sederhana pun dapat disebut pesawat misalnya sendok, obeng, sekrup, dan sapu. Energi yang dikeluarkan oleh seorang pekerja semakin kecil. Media pembelajaran yang dikembangkan memiliki spesifikasi sebagai berikut:

1. Media yang memuat standar kompetensi, kompetensi dasar, indikator, animasi, materi, dan video pada materi pesawat sederhana yang menarik.

2. Media yang dikembangkan memuat materi pesawat sederhana untuk siswa SMP kelas VIII.

3. Multimedia ini dapat digunakan dalam pembelajaran di kelas.

4. Media pembelajaran yang dikembangkan berupa Powerpoint yang terintegrasi dengan LKS dan interaktif.

5. LKS disini agar siswa memiliki kemampuan untuk memecahkan persoalan-persoalan mengenai materi pembelajaran tentang pesawat sederhana.

6. Bersifat interaktif maksudnya yaitu mengajak siswa untuk melibatkan pikiran, pengelihatan, pendengaran, dan keterampilan.

Tujuan penelitian pengembangan multimedia powerpoint yaitu (1) Menghasilkan media pembelajaran fisika multimedia interatif terintegrasi powerpoint dengan LKS pada pokok bahasan pesawat sederhana yang mudah di gunakan untuk siswa dalam pembelajaran. (2) Mengetahui tingkat kelayakan atau tidak layaknya media pembelajaran fisika yang dikembangkan oleh peneliti terhadap multimedia interaktif powerpoint terintegrasi dengan LKS pada pokok bahasan pesawat sederhana yang baik di gunakan untuk pembelajaran siswa.(3) Mengetahui mudahnya mengoperasikan pada produk powerpoint dalam pembelajaran yang dilakukan oleh guru di dalam kelas.

\section{METODE PENELITIAN}

Jenis penelitian produk ini merupakan penelitian pengembangan (Research and Development). Model pengembangan yang digunakan oleh peneliti adalah model pengembangan prosedural. Jenis pengembangan prosedural ini menggambarkan langkah awal dan langkah akhir secara berurutan untuk menghasilkan suatu produk tertentu, dalam penelitian pengembangan produk ini yang dihasilkan adalah media powerpoint. Penelitian ini peneliti menggunakan model pegembangan ADDIE (Menurut Chaeruman dalam Aththibby, 2011:17) meliputi lima tahap yaitu: (1)Analysis, (2)Design, (3)Development, (4)Implementation, (5) dan Evaluation. Penjelasan dari lima tahap dari pengembangan ADDIE meliputi:

1. Analysis ( analisis) hasil dari tahap wawancara atau prasurvei.

2. Design (perencanaan) kerangka pengembangan multimedia interaktif terintegrasi dengan LKS berupa powerpoint.

3. Development (produksi) produk pengembangan multimedia interaktif terintegrasi dengan LKS berupa powerpoint.

4. Implementation (implementasi) validasi produk oleh uji ahli media dan ahli materi.

5. Dan Evaluation (evaluasi) uji di lapangan oleh respon guru dan respon siswa. 


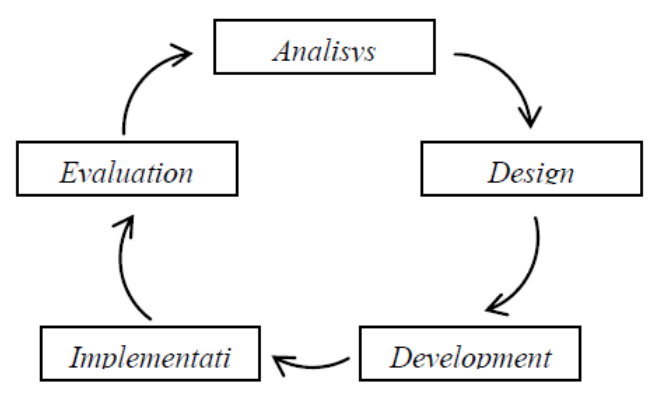

Gambar 1. Rancangan Penelitian

Uji coba produk ini untuk mengumpulkan data yang akan dipakai sebagai dasar untuk mendapatkan tingkat kelayakan suatu produk yang dihasilkan untuk penelitian.

1. Desain Uji Coba

Uji coba produk ini dilakukan melalui dua tahapan, yaitu uji ahli dan uji angket terdiri dari respon guru dan respon siswa. Pada tahap uji ahli, pengujian dilakukan uji ahli produk pada media powerpoint, pada powerpoint ini terdapat aspek yang digunakan yaitu sebagai berikut: (aspek rekayasa perangkat lunak dan aspek komunikasi visual) serta ahli materi (desain pembelajaran). Uji ahli adalah menilai mutu terhadap produk media powerpoint baik dari desain media maupun penyajian materi. Sedangkan, uji angket yang adalah untuk melihat respon guru serta respon siswa mengenai kemudahan produk yang akan dipakai oleh pengguna.

2. Subyek Coba

a. Uji ahli

Uji ahli ini dimaksudkan untuk mengetahui apakah produk yang telah dikembangkan dapat dijadikan sebagai media pembelajaran. Kriteria media yang dinilai meliputi, (rekayasa perangkat lunak, komunikasi visual) dan materi (desain pembelajaran). Uji coba terhadap produk tersebut dapat dilakukan dengan memberikan lembar validasi kepada beberapa ahli yaitu: ahli media dan materi yang sudah berpengalaman untuk menilai produk yang baru dirancang. Uji coba produk ini akan di uji oleh ahli, yaitu satu dosen, dua guru yang sudah mengerti dan memahami secara terperinci. Hasil uji ahli tersebut digunakan sebagai bahan pertimbangan dalam melakukan revisi produk yang sudah dikembangkan.

b. Uji angket

Uji coba ini bertujuan untuk melihat bagaimana hasil respon guru serta respon siswa mengenai kemudahan serta keinteraktifan media pembelajaran powerpoint terintegrasi $L K S$ yang telah dikembangkan. Kemudahan dan keinteraktifan produk pada respon guru dan respon siswa berdasarkan kriteria komunikasi visual, namun pada respon guru terdapat pula aspek desain pembelajaran dan kriteria komunikasi visual.

3. Jenis Data

Penelitian pengembangan ini adalah Instrumen Lembar validasi ahli yang dimaksud adalah validasi ahli terhadap produk media pembelajaran powerpoint terintegrasi LKS yang dikembangkan. Angket yang dimaksud adalah angket respon guru serta repon siswa terhadap produk media pembelajaran powerpoint terintegrasi LKS yang dikembangkan.

4. Instrumen Pengumpulan Data

Instrumen yang digunakan dalam mengumpulkan data penelitian ini terdiri dari dua jenis instrumen, yakni lembar validasi media pembelajaran dan angket. Lembar validasi media pembelajaran, merupakan instrumen yang digunakan pada tahap pengujian produk oleh beberapa ahli. Sedangkan angket terdiri dari dua, yakni angket angket respon guru dan respon siswa yang berisi beberapa pernyataan yang diminta untuk ditanggapi.

5. Teknik Analisis Data

Setelah data diperoleh selanjutnya adalah menganalisis data tersebut penelitian ini lebih menitik beratkan pada bagian mengembangkan media pembelajaran powerpoint terintegrasi LKS sehingga data dianalisis dengan sistem deskriptif persentase. Analisis yang dilakukan pada penelitian ini yaitu dengan cara mengelompokan jenis-jenis data yang diperoleh sehingga peneliti mudah memahami data dan menarik kesimpulan. Dengan validasi kelayaan intrumen dan media terdapat ahli yang memvalidasi yaitu: satu dosen dan dua guru. 


\section{HASIL DAN PEMBAHASAN}

Hasil pada uji coba produk oleh ahli yang dilakukan untuk menguji kelayakan media powerpoint apakah sudah memenuhi kriteria yang sangat layak atau tidak layak. Analisis data pada media powerpoint yang di uji oleh ahli aspek perangkat lunak dan aspek komunikasi visual mencapai presentase sebagai berikut:

\begin{tabular}{|c|c|c|c|}
\hline $\mathrm{No}$ & Aspek yang dinilai & $\%$ & Kriteria \\
\hline 1. & $\begin{array}{l}\text { Aspek perangkat lunak dan aspek } \\
\text { komunikasi visual }\end{array}$ & 89,1 & $\begin{array}{l}\text { SANGAT } \\
\text { LAYAK }\end{array}$ \\
\hline 2. & Aspek desain pembelajaran & 89,0 & $\begin{array}{l}\text { SANGAT } \\
\text { LAYAK }\end{array}$ \\
\hline
\end{tabular}

Hasil pada uji coba produk oleh Respon Guru dan Respon Siswa yang dilakukan untuk mengetahui kelayakan media powerpoint apakah sudah memenuhi kriteria yang sangat baik atau tidak baik. Analisis data pada media powerpoint yang di uji di lapangan mencapai presentase sebagai berikut:

\begin{tabular}{cllcc}
\multicolumn{2}{l}{ Tabel 2. Uji Lapangan } & & & \\
\hline No & \multicolumn{1}{c}{ Angket } & Aspek yang di nilai & $\%$ & kriteria \\
\hline 1. & $\begin{array}{l}\text { Angket } \\
\text { respon } \\
\text { guru }\end{array}$ & $\begin{array}{l}\text { Aspek desain } \\
\text { pembelajaran dan aspek } \\
\text { komunikasi visual }\end{array}$ & 90,5 & $\begin{array}{c}\text { SANGAT } \\
\text { BAIK }\end{array}$ \\
\hline 2. & $\begin{array}{l}\text { Angket } \\
\text { respon siswa }\end{array}$ & Aspek komunikasi visual & 87,1 & $\begin{array}{c}\text { SANGAT } \\
\text { BAIK }\end{array}$ \\
\hline
\end{tabular}

Berdasarkan uji coba produk terdapat uji ahli satu dosen dan dua guru selanjutnya uji coba lapangan terhadap tiga respon Guru dan dan dua puluh tujuh respon Siswa mendapat kriteria pada produk yang berupa powerpoint yaitu: kriteria sangat layak dan kriteria sangat baik, sehingga dapat digunakan dalam proses pembelajaran. Produk pengembanan multimedia interaktif terintegrasi dengan LKS pada pokok bahasan pesawat sederhana berupa powerpoint sebagai pemecah masalah di sekolah yang di lakukan oleh peneliti, permasalah yang ada disekolah, dan solusinya. Permasalahan media pembelajaran dan sarana prasarana yang ada di sekolah media yang digunakan belum dapat membantu pembelajaran siswa, selanjutnya metode yang digunakan guru tersebut masih bersifat monoton, guru menggunakan metode yang sama dan berulang-ulang dan penggunaan multimedia interkatif terintegrasi LKS disekolahan sudah ada, tetapi adanya kendala pada sarana dan prasarana. Solusi pemecah masalah di sekolah yang diteliti oleh peneliti terdapatnya mulitimedia adalah suatu media yang diartikan lebih dari satu media yaitu: teks, grafis, gambar, poto, audio dan animasi. Media yang ada di sekolah belum interaktif, perlu adanya Interaktif adalah suatu alat yang dapat di operasikan oleh pengguna sehingga pengguna mudah untuk menjalankan media yang diinginkan. Selanjutnya LKS yang digunakan belum terinterasinya kemedia perlunya adanya Terintegrasi LKS adalah suatu penggabungan, media powerpoint yang di dalamnya terdapat Lembar Kerja Siswa (LKS).

Kelebihan pada media powerpoint ini bisa dibuka pada smartphone dan tidak perlu memasukkan file video kedalam smartphone, hanya file media powerpoint yang di copy kedalam smartphone maka video akan tampil slide show. Diharapkan siswa dapat belajar lebih interaktif. Serta terdapat konsep-konsep yang mendukung pembelajaran siswa meliputi: video, animasi, gambar dalam materi pesawat sederhana sehingga mempermudah siswa dalam belajar. Pada media ini bahasa yang digunakan sederhana sehingga mempermudah guru menjelaskan konsep-konsep terhadap siswa. Dapat disimpulkan bahwa pengembangan media powerpoint terintegrasi dengan LKS pada pokok bahasan materi pesawat sederhana sangat layak digunakan untuk proses pembelajaran fisika.

Media powerpoint diharapkan dapat digunakan oleh pengguna dalam pembelajaran di kelas dengan mudah. Sehingga dibutuhkan pengembangan multimedia powerpoint terintegrasi LKS pada pokok bahasan pesawat sederhana yang mempermudah siswa dalam proses pembelajaran. Selanjutnya Media powerpoint ini dalam materi pembelajaran fisika dikembangkan pada materi pesawat sederhana, sehingga diharapkan ada pengembangan produk pada materi pelajaran fisika yang lain. Pengunaan silabus dari pengembangan ini menggunakan KTSP diharapkan adanya pengembangan produk menggunakan kurikulum 2013 atau kurikulum yang baru dalam pengembangan yang lain. 


\section{PENUTUP}

Hasil pengembangan produk pada Aspek Rekayasa Perangkat Lunak dan Aspek Komunikasi Visual mendapat presentase $89,1 \%$ pada pencapaian kelayakan sangat layak. Sedangkan pada Aspek Desain Pembelajaran mendapatkan presentase $89,0 \%$ pada pencapaian kelayakan sangat layak. Hasil uji coba lapangan dengan menggunakan angket respon guru memperoleh presentase $90,5 \%$ pada penilaian sangat baik. Dan penilaian angket respon siswa mendapat presentase $87,1 \%$ pada penilaian sangat baik.

\section{DAFTAR PUSTAKA}

Ariani Niken dan Haryanto Dany. 2010. Pembelajaran Multimedia Di Sekolah Pedoman Pembelajaran Inspiratif, Kontruktif dan Prospektif. Jakarta: PT Prestasi Pustakaraya.

Arsyad, Azhar. 2013. Media Pembelajaran (Edisi Revisi). Jakarta: PT Raja Grafindo Persada

Anggraini, Yelsi. 2012. Penerapan Media PowerPoint Untuk Meningkatkan Kemampuan Mengenal Huruf Vokal Bagi Anak Tunarungu. Volume 1 Nomer 1 Januari 2012. Payakumbuh:UNP

Aththibby, Arif Rahman, Ishafit. 2011. Perancangan Media Pembelajaran Fisika Berbasis Animasi Komputer untuk Sekolah Menengah Atas Pokok Bahasan Hukum Newton Tentang Gerak. Universitas Negeri Yogyakarta: Prosiding Seminar Nasional Penelitian, Pendidikan dan Penerapan MIPA.

Harjono. 2007. Pokok-pokok Fisika Smp untuk kelas VIII. Jakarta: Erlangga.

Trianto. 2009. Mendesain Model Pembelajaran Inovatif-Progresif. Jakarta: Prenada Media.

Trianto, 2011. Model Pembelajaran Terpadu Knsep Strategi, dan Implementasinya Dalam Kurikulum Tingkat Satuan Pendidikan. Jakarta: PT Bumi Aksara.

Triatmanto. 2007. Ilmu Pengetahuan Alam Terpadu. Untuk Smp Dan Mts Kelas VIII Jakarta: Karya Mandiri Nusantara.

Sari, W. M., Riswanto, R., \& Partono, P. (2019). Validitas mobile pocketbook berbasis android menggunakan adobe flash pada materi suhu dan kalor. Berkala Ilmiah Pendidikan Fisika, 7(1), 35-42 